\title{
The Effect of Chlorhexidine Gluconate as an Endodontic Irrigant on the Apical Seal: Long-term Results
}

David B. Ferguson

Virginia Commonwealth University

Follow this and additional works at: https://scholarscompass.vcu.edu/etd

Part of the Endodontics and Endodontology Commons

(C) The Author

\section{Downloaded from}

https://scholarscompass.vcu.edu/etd/1408

This Thesis is brought to you for free and open access by the Graduate School at VCU Scholars Compass. It has been accepted for inclusion in Theses and Dissertations by an authorized administrator of VCU Scholars Compass.

For more information, please contact libcompass@vcu.edu. 
The Effect of Chlorhexidine Gluconate as an Endodontic Irrigant on the Apical Seal:

Long-term Results

A thesis submitted in partial fulfillment of the

Requirements for the degree of Master of Science at

Virginia Commonwealth University

by

David B. Ferguson, D.D.S.

University of Missouri-Kansas City 1990

Director: Gary R. Hartwell, D.D.S., M.S.

Department of Endodontics

Virginia Commonwealth University

Richmond, Virginia

February 28, 2003 


\section{Acknowledgement}

The author wishes to thank several people. I would like to thank Drs. Peter Moon, Ellen Hahn for all their help and direction, Dr. Al Best for the statistical analysis, and Dr. David Pashley for allowing the use of his fluid filtration apparatus. Additionally, I wish to thank Dr. John T. Marley, who provided methodological guidance, and spent countless hours working with me on this project. Specifically, I would like to thank Dr. Gary Hartwell for his unending leadership, compassion, mentoring and support during the residency. I would also like to thank my wife Lillian, and my family for their love, support and patience. Finally, I give thanks to God for restoring my health, and allowing me the strength to complete this project. 
Table of Contents

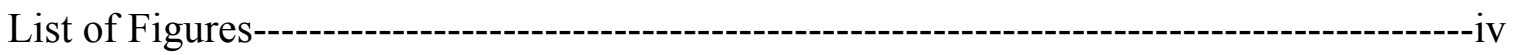

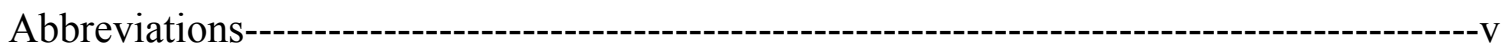

Abstract--------------------------------------------------------------------------------------------------------vi

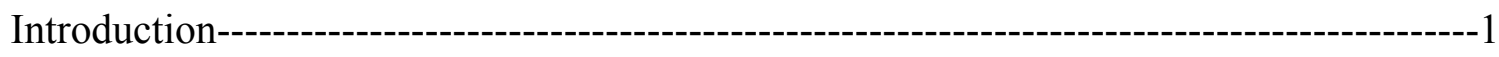

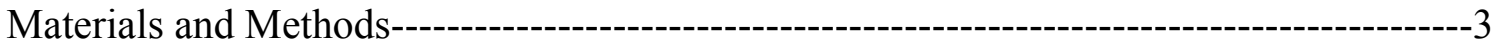

Results-----------------------------------------------------------------------------------------------------1

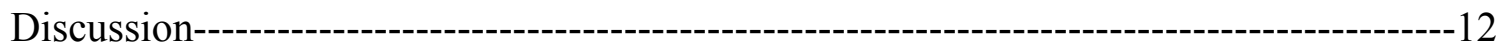

Literature cited---------------------------------------------------------------------------------------------15

Vita--------------------------------------------------------------------------------------------------------17 


\section{List of Figures}

\section{Figures}

1. Fluid Filtration Apparatus------------------------------------------------------------------------'6

2. Mean leakage trends across time for each irrigant / sealer combination in $\mu 1 / \mathrm{min}----9$

3. Estimated LS means and 95\% confidence intervals for each intervention at 360-days

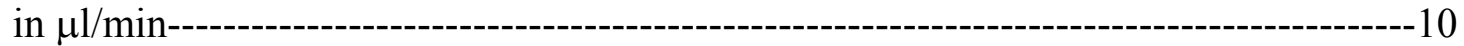

4. Estimated LS means and 95\% confidence intervals for each intervention at 360-days

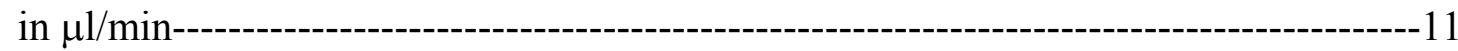


Abbreviations

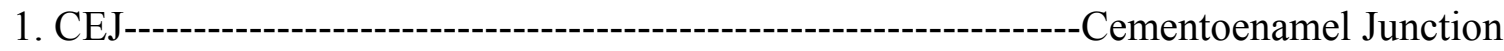

2. psi------------------------------------------------------------------------Pounds Per Square Inch

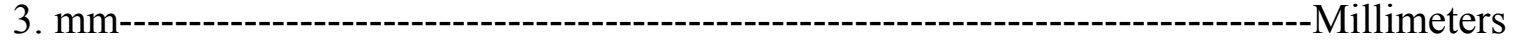

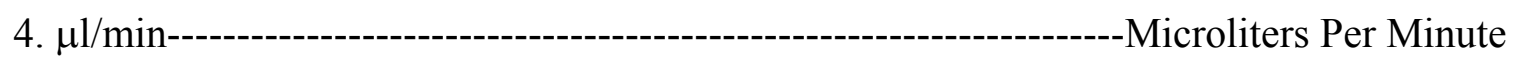

5. HSD-----------------------------------------------------------Honestly Significant Difference

6. ANOVA--------------------------------------------------------------------Analysis of Variance 


\begin{abstract}
THE EFFECT OF CHLORHEXIDINE GLUCONATE AS AN ENDODONTIC IRRIGANT ON THE APICAL SEAL: LONG-TERM RESULTS
\end{abstract}

\author{
By David B. Ferguson, D.D.S.
}

A thesis submitted in partial fulfillment of the requirements for the degree of Master of Science at Virginia Commonwealth University

Virginia Commonwealth University, 2002

Major Director: Gary R. Hartwell, D.D.S., M.S.

Chairman and Professor, Department of Endodontics

The purpose of this study was to determine whether chlorhexidine gluconate $(0.12 \%)$, used as an endodontic irrigating solution would affect the apical seal of three root canal cements. One hundred extracted human single-canal teeth were divided into 9 experimental groups of 10 teeth each, in addition to a positive and negative control group of 5 teeth each. The teeth were decoronated at the level of the cementoenamel junction, accessed, instrumented to a Master Apical File \#50, irrigated with either sterile saline, $5.25 \% \mathrm{NaOCl}$ or $0.12 \%$ chlorhexidine gluconate, and dried using paper points. Obturation was accomplished using lateral condensation and one of three endodontic sealers: Roth's 811, AH26, or Sealapex. Post-obturation apical leakage was measured at 270- and 360-day observation periods using the fluid filtration method. Using the mixedmodel repeated-measures ANOVA test with Tukey’s HSD multiple comparison 
procedure, the results showed the saline-Sealapex combination had significantly more leakage $(p<0.05)$ than either the Peridex-Sealapex or saline-Roth's combinations at 270 days. No other significant differences were noted between any sealer-irrigant combination at 270 days. The saline-Sealapex combination had significantly more leakage than the saline-Roth's combination at 360 days. No other significant differences were noted at 360 days. Under the conditions of this study, chlorhexidine gluconate irrigant did not adversely affect the apical seal of three root canal cements at 270 and 360 days. 
Introduction

One of the most important objectives in nonsurgical endodontic therapy is to disinfect the entire root canal system before obturation of the canals. Sodium hypochlorite has long been the irrigant of choice because of its antimicrobial activity and tissue dissolving ability, but it has been found to cause severe inflammatory reactions when placed in contact with vital tissues (1-2).

Chlorhexidine gluconate is recognized as being an effective oral antimicrobial agent and is routinely used in periodontal therapy and for caries prevention (3). Chlorhexidine, in the form of a salt, has been used since the 1950's as an oral antiseptic in mouthwash, toothpaste, and chewing gum (4). Chlorhexidine has been found to have broadspectrum antimicrobial action (5), substantivity $(4,6)$, and a relative absence of toxicity (5). These properties have led to the suggestion that this solution may have some potential use as an irrigant in endodontics. A search of the literature failed to reveal any studies that have investigated what effect chlorhexidine may have on endodontic cements and their ability to seal the root canal system.

The assessment of the sealing ability of root canal obturation materials has been investigated by numerous investigators $(7,8)$. The most widely used technique to evaluate apical seal has been the measurement of linear dye penetration (9). Studies have 
shown that entrapment of air bubbles may exert a negative impact on the dye leakage and have suggested the use of a positive pressure system to obtain a more realistic result (10). The purpose of this study was to evaluate whether chlorhexidine gluconate $(0.12 \%)$, when used as an endodontic irrigant, would affect the seal obtained when using three different endodontic cements. This study reports the long-term results obtained at 270and 360-day observation periods. The short-term results published in a previous study by the same authors revealed no significant differences between irrigants, and sealers at 90and 180-day observation periods (11). 


\section{Materials and Methods}

One hundred extracted human single-rooted teeth were used in this investigation. The teeth were randomly divided into nine experimental groups of ten teeth each and a positive and negative control group of five teeth each. All procedures were conducted by two operators. All instrumentation procedures were performed by one investigator and all obturation procedures by the other. This technique provided continuity of treatment throughout each section of the experiment. The teeth were stored in sterile saline $(0.9 \%$ sodium chloride) before the initiation of the experiment. The teeth were decoronated at the level of the cementoenamel junction using a carborundum disk, and the root surfaces were debrided of tissue as needed.

The working lengths were determined by placing a \#10 file into the root canal until it was visible at the apical foramen and subtracting $1 \mathrm{~mm}$ from that length. The canals were prepared in a step-back manner using Flexofiles (Dentsply/Caulk, Milford, DE) and Gates Glidden drills (Moyco Industries Inc./Union Broach Division, NY, NY) to a master apical file size of \#50. Three milliliters of irrigant was used after every change of Gates Glidden drill or endodontic file. Three different irrigating solutions were used in this study. Teeth in groups 1 to 3 were irrigated using sterile saline ( $0.9 \%$ sodium chloride, Baxter Healthcare Corporation Deerfield, IL), teeth in groups 4 to 6 were irrigated using $5.25 \%$ sodium hypochlorite (Clorox, Oakland, CA), and teeth in groups 7 to 9 were 
irrigated using $0.12 \%$ chlorhexidine gluconate (Peridex, Zila Pharmaceuticals, Inc, Cincinnati, $\mathrm{OH})$. Both control groups were irrigated using sterile saline.

After instrumentation, the root canals were dried with paper points (Dentsply/Caulk), and a \#50 master gutta-percha cone (Hygenic Corporation, Akron, $\mathrm{OH}$ ) was fitted to working length. A \#10 file was also passed through the apical foramen to ensure apical patency. A gutta-percha lateral condensation technique was used to obturate all nine experimental groups. In groups 1, 4, and 7 Roth's 811 sealer (Roth International Ltd., Chicago IL) was used. AH26 sealer (Dentsply/Caulk) was used in groups 2, 5, and 8, and Sealapex sealer (Kerr Corporation, Romulus, MI) as used in groups 3, 6, and 9. The positive control group was obturated with gutta-percha without sealer, and the negative control group was obturated using lateral condensation of gutta-percha and Roth's 811 sealer. Immediately after obturation, gutta-percha was removed to a level $5 \mathrm{~mm}$ from the working length using a Touch 'n Heat (Analytic Technology/Kerr). This measurement was verified using radiographs. The roots of all experimental groups and the positive control were coated with two coats of clear nail polish (Revlon) except for the apical 2 $\mathrm{mm}$. The entire root and apical foramen of the negative control was completely covered with two coats of the nail polish. Using the method described by Derkson and Pashley (12) the teeth were bonded to Plexiglass blocks using cyanoacrylate, and the exposed portions of the roots were submerged in a $0.2 \%$ sodium azide solution during the time period between microleakage measurements. Microleakage was measured using the fluid 
filtration method under $10 \mathrm{psi}$. The system was infused with $0.2 \%$ fluorescein dye to aid in the visualization of any leakage that occurred throughout the root canal system or cyanoacrylate interfaces. Once the system was activated under $10 \mathrm{psi}$, a 2-minute stabilization period was provided for each tooth. After this stabilization period the samples were measured for 1-minute, four times in succession at each time interval of 270 and 360 days. Measurements were averaged and converted to microliters per minute. The experiment is a $3 \times 3$ design with two detached control groups. The two interventions were: (a) Endodontic irrigating solutions ( $\mathrm{NaOCl}, 0.12 \%$ Chlorhexidine gluconate, and saline), and (b) Endodontic obturating sealers (AH 26, Roth's 811, and Sealapex). The results were analyzed using mixed-models repeated-measures ANOVA with Tukey's HSD multiple comparison procedure and significance set at $p<0.05$. The 90- and 180-day results were analyzed in an earlier study (11). 


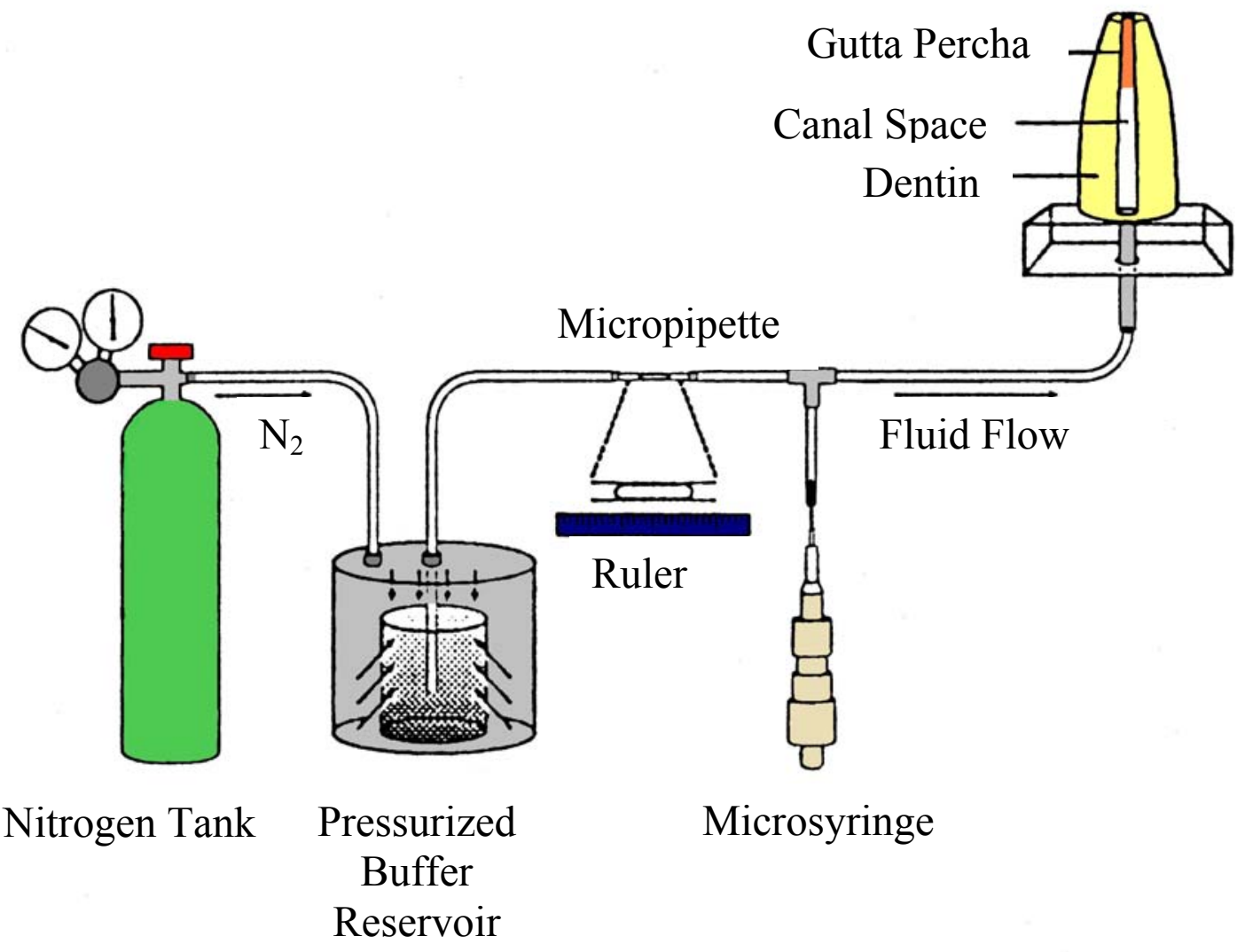

Figure 1 Fluid Filtration Apparatus 
Results

The leakage of the negative controls were all uniformly zero and the leakage of the positive controls were all immeasurably high. The 270 - and 360-day observation periods were analyzed separately.

As reported in the previous paper, at the 90-day observation point, the ANOVA results showed no significant difference due to irrigation main effect $(p=0.9962)$, sealant main effect $(p=0.7145)$, nor the interaction $(p=0.5175)$. Similarly at the 180 -day observation point, the ANOVA results showed no significant difference due to the irrigation main effect $(p=0.3558)$, sealer main effect $(p=0.3812)$, nor the interaction $(p=0.7493)$. The full ANOVA results for the 270- and 360-day trials showed no significant difference due to irrigation main effect $(p=0.1315)$, sealer main effect $(p=0.4248)$, nor the interaction $(\mathrm{p}=0.0557)$. However, the three-way interaction of irrigation, sealer, and days is significant $(\mathrm{p}=0.0052)$. That is, the effects of irrigation, sealer, and days each depend on the others and so simple interpretation of any main-effect or two-way interaction is problematic. The mean leakage for each experimental condition in both Parts I and II is shown in Figure 1 and illustrates that trends across time are not parallel. While most sealer-irrigant combinations tended to leak less over time, the salineSealapex and saline AH26 combinations did not. 
At the 270-day time interval, a significant difference emerges. At this time point, there is a significant interaction between sealer and irrigation method $(p=0.0125)$. The estimated LS mean leakage values of all irrigant-sealer combinations at 270 days are shown in Figure 2. Tukey's HSD multiple comparison procedure indicated that the saline-Sealapex combination has significantly higher leakage than either PeridexSealapex or saline-Roth's. There were no other significant differences at 270 days. At the 360-day time interval, there was also a significant irrigation-sealer interaction $(\mathrm{p}=$ 0.0300). The estimated LS mean leakage values of all irrigant-sealer combinations at 360 days are shown in Figure 3. Tukey's HSD multiple comparison procedure indicated that the saline-Sealapex combination has significantly higher leakage than saline-Roth's. There were no other significant differences at 360 days. 


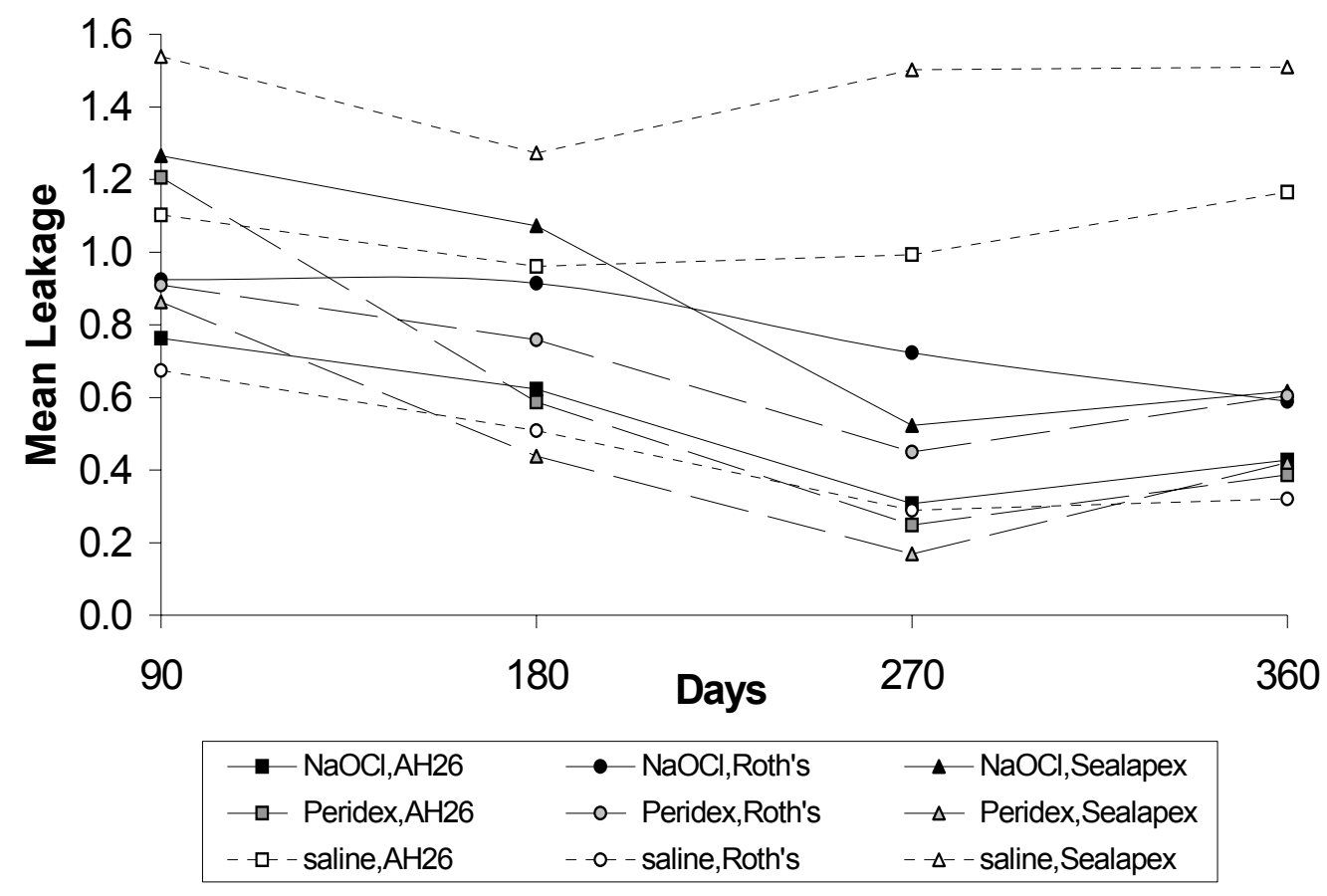

Figure 2 Mean leakage trends across time for each irrigant / sealer combination in $\mu \mathrm{l} / \mathrm{min}$ 


\section{Days}

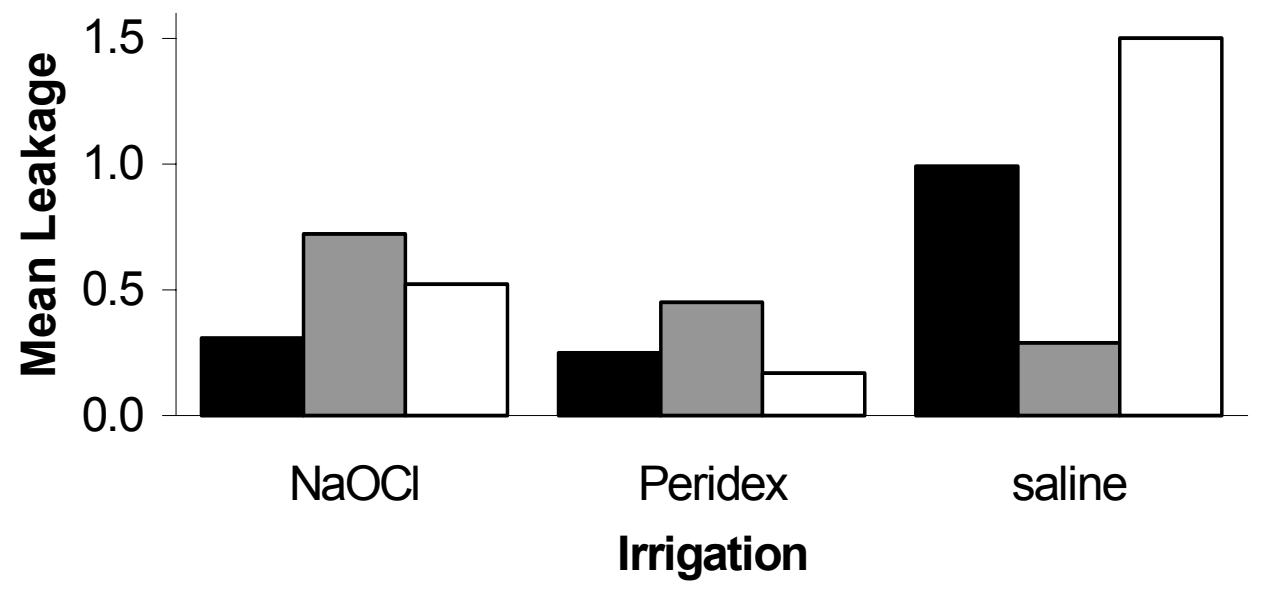

aH26 $\square$ Roth's $\square$ Sealapex

Figure 3 Estimated LS means and $95 \%$ confidence intervals for each intervention at 270 -days in $\mu \mathrm{l} / \mathrm{min}$ 


\section{Days}

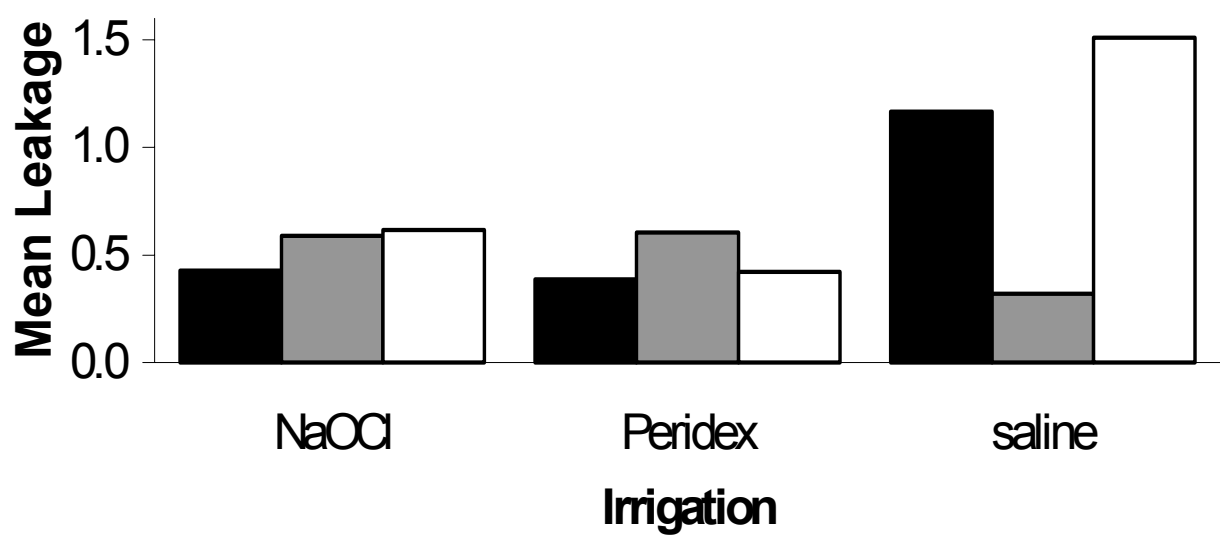

口A-26 $\square$ Roth's $\quad \square$ Sealapex

Figure 4 Estimated LS means and $95 \%$ confidence intervals for each intervention at 360-days in $\mu \mathrm{l} / \mathrm{min}$ 


\section{Discussion}

Chlorhexidine in the chemical form is a cationic bis-biguanide that is primarily marketed as a gluconate salt. A commercially available oral rinse contains $0.12 \%$ chlorhexidine gluconate in a base containing water, $11.6 \%$ alcohol, glycerine, flavoring agents, and saccharin. Approximately $30 \%$ of the active ingredient is retained in the oral cavity after rinsing and is slowly released into the oral fluids (13). This substantive antimicrobial activity has been identified as a potentially protective element in the canal tissues for many hours after instrumentation (14). The potential for chlorhexidine gluconate use in endodontics has been clearly demonstrated by numerous investigators $(1,2,15-18)$; however there is a lack of research regarding the effects of chlorhexidine gluconate on the apical sealing ability of some common endodontic sealers. Many investigators have studied and compared the sealing ability of different endodontic sealers. Lim and Tidmarsh (9), using an electrochemical leakage method, determined that Sealapex exhibited significantly less leakage than AH26 at 12 wk, but at 26 wk there was no significant difference. Wu et al. (19), using the fluid transport model, revealed that $\mathrm{AH} 26$ had a reduction in leakage over time and demonstrated significantly less leakage than Sealapex.

This study was undertaken to determine whether chlorhexidine gluconate, used as an endodontic irrigant, would adversely effect the sealing ability of three endodontic sealers. 
Our study also used a fluid filtration method that allowed us to examine quantitatively the leakage of teeth over time. In contrast to previous studies, our short-term results demonstrated no significant differences in apical leakage using three irrigants (sterile saline, 5.25\% sodium hypochlorite, and Peridex) and three different sealers (Roth's 811 , Sealapex, and AH26) at both 90- and 180-day observation periods. Our long-term results using the same combinations of sealers and irrigants indicated that the saline-Sealapex combination has significantly higher leakage than either Peridex-Sealapex or salineRoth's combinations at 270- days. At 360-day observations, our data indicated that the saline-Sealapex combination has significantly higher leakage than saline-Roth's. The fluid filtration method proved to be very technique-sensitive. There was a tendency for leakage to occur at the Plexiglass/cyanoacrylate interface that made it necessary to remove the old adhesive and reattach the teeth to the Plexiglass block with fresh cyanoacrylate at each observation period. Teeth were stored in closed containers with the apical root ends suspended in the $0.2 \%$ sodium azide solution and maintained in a 98.0 degree incubator between the observation periods. Because cyanoacrylate is a waterbased adhesive the breakdown at the interface was expected. Teeth fractured during the reattachment process were eliminated from the study. While both chlorhexidine gluconate and sodium hypochlorite are effective as antimicrobial agents, chlorhexidine gluconate has the possible clinical advantage of being relatively non-toxic to vital tissue (2). This could influence a decision to use 
chlorhexidine gluconate in teeth with perforations, open apices, or difficult isolation cases. Another advantage of using chlorhexidine gluconate is that it could be used for patients that are allergic to sodium hypochlorite (20). The major disadvantage of using chlorhexidine gluconate as the primary endodontic irrigant is that it lacks the ability to dissolve necrotic pulp tissue.

The results of this study demonstrate significantly higher leakage from the salineSealapex combination than either Peridex-Sealapex or saline-Roth's combination at 270days, and significantly higher leakage from the saline-Sealapex combination than the saline-Roth's combination at 360-days. These results may confirm the findings of Wu et al. (19), that Sealapex breaks down over time when in contact with fluids, thereby reducing its sealing ability unless the thickness layer of sealer was very thin $(0.05 \mathrm{~mm})$. No effort was made in this study to control or measure the thickness layers of any sealer. Each sealer was mixed and handled as directed by the manufacturer. The fact that the Peridex-Sealapex combination provided significantly better seal than the saline-Sealapex combination cannot be explained. The results of this study showed that $0.12 \%$ chlorhexidine gluconate when used as an endodontic irrigant does not adversely affect the apical seal when using either Roth's, AH 26, or Sealapex sealers. 


\section{Literature Cited}

1. Yesiloy C, Whitaker E, Cleveland D, Phillips E, Trope M. Antimicrobial and toxic effects of established and potential root canal irrigants. J Endodon 1995;21:513-5.

2. Jeansonne MJ, White RR. A comparison of $2 \%$ chlorhexidine gluconate and $5.25 \%$ sodium hypochlorite as antimicrobial endodontic irrigants. J Endodon 1994;20:2768 .

3. Fardal O, Turnbull RS. A review of the literature on use of chlorhexidine in dentistry. J Am Dent Assoc 1986;112:863-9.

4. Leonardo MR, Tanomaru Filho M, Silva LAB, Nelson Filho P, Bonifacio KC, Ito IY. In vivo antimicrobial activity of $2 \%$ chlorhexidine used as a root canal irrigating solution. J Endodon 1999;25;167-71.

5. Lee LW, Lan WH, Wang GY. An evaluation of chlorhexidine as an endosonic irrigant. J Formos Med Assoc 1990;89:491-7.

6. Parsons GJ, Patterson SS, Miller CH, Katz S, Kafrawy AH, Newton CW. Uptake and release of chlorhexidine by bovine pulp and dentin specimens and their subsequent acquisition of antibacterial properties. Oral Surg 1980;49:455-9.

7. Branstetter J, von fraunhofer JA. The physical properties and sealing action of endodontic sealer cements: a review of the literature. J Endodon 1982;8:312-6.

8. Lim KC, Tidmarsh BG. The sealing ability of sealapex compared with AH-26. J Endodon 1986;12:564-6.

9. Wu MK, Wesselink PR. Endodontic leakage studies reconsidered. Part I. Methodology, application and relevancy. Int Endod J 1993;26:37-43.

10. Oliver CM, Abbott PV. Entrapped air and its effects on dye penetration of voids. Endod Dent traumatol 1991;7:135-8.

11. Marley JT, Ferguson DB, Hartwell, GR. Effects of chlorhexidine gluconate as an endodontic irrigant on the apical seal: short-term results. J Endodon; In Press. 
12. Derkson GD, Pashley DH, Derkson ME. Microleakage measurement of selected restorative materials: a new in vitro method. J Prosthet Dent 1986;56:435-40.

13. Genco RJ, Goldman HM, Cohen DW. Contemporary periodontics. $1^{\text {st }}$ ed. St. Louis: Mosby Company, 1990:167.

14. White RR, Hays GL, Janer LR. Residual antimicrobial activity after canal irrigation with chlorhexidine. J Endodon 1997;23:229-31.

15. Vahdaty A, Pitt-Ford TR, Wilson RF. Efficacy of chlorhexidine in disinfecting dentinal tubules in vitro. Endod Dent Traumatol 1993;9:243-8.

16. Ohara P, Torabinejad M, Kettering JD. Antibacterial effects of various endodontic irrigants on selected anaerobic bacteria. Endod Dent traumatol 1993;9:95-100.

17. Orstavik D, Haapasalo M. Disinfection by endodontic irrigants and dressings of experimentally infected dentinal tubules. Endod Dent Traumatol 1990;6:142-9.

18. Ringen AM, Patterson SS, Newton CW, Miller CH, Mulhern JM. In vivo evaluation of chlorhexidine gluconate solution and sodium hypochlorite solution as root canal irrigants. J Endodon 1982;8:200-4.

19. Wu MK, Wesselink PR, Boersma J. A 1-year follow-up study on leakage of four root canal sealers at different thicknesses. Int Endod J 1995;28:185-9.

20. Kaufman AY, Keila S. Hypersensitivity to sodium hypochlorite. J Endodon 1989;15:224-6. 
Vita

David B. Ferguson was born on May 31, 1964 in St. John, Kansas. He graduated from McPherson High School, McPherson, Kansas in 1982. He attended Kansas State University in Manhattan, Kansas where he received a Bachelor of Science degree in 1986. He attended the University of Missouri-Kansas City School of Dentistry in Kansas City, Missouri where he earned a Doctor of Dental Surgery degree in 1990. Subsequently, he was commissioned in the United States Army, where he currently serves as a Lieutenant Colonel. He has served at various locations in the United States, Germany, and Bosnia. He received a Certificate in Endodontics and a Master of Science degree from Virginia Commonwealth University in 2003. 